\title{
EDITORIAL
}

\section{The Barcelona Declaration from the World Alliance against Antibiotic Resistance: engagement of intensivists}

\author{
Jean M Carlet*1, Antonio Artigas², Michael S Niederman ${ }^{3}$ and Antoni Torres ${ }^{4}$, on behalf of World Alliance against \\ Antibiotic Resistance
}

Resistance to antibiotics is increasing dangerously worldwide [1]. Our very last line of therapy, carbapenems, is nowadays often needed to treat community-acquired infections. As a result, resistance to this class will increase very quickly, leaving us with almost no useful drugs against multi-resistant bacteria.

Microorganisms resistant to almost every antibiotic are already present in the ICUs of many countries, requiring the use of old and toxic antibiotics such as colistin [2]. We were usually saved from resistance in the past by the regular introduction of new compounds, but this time the pipeline is almost dry. No new antibacterial agent active against Gram-negative bacteria is expected in the next 5 years. We are therefore back in the situation of 50 years ago, and the risk of large epidemic outbreaks leading to a real pandemic with those multi-resistant bacteria is real. The European Centre for Diseases Control estimate is that 25,000 patients in Europe might die from infections due to resistant organisms every year. In most countries, people use too many antibiotics empirically - in particular, to treat viral infections such as pharyngitis, bronchitis, or urinary colonisation. To treat severe infections in the ICU, and for the sake of their patients, prescribers use broad-spectrum antibiotics empirically in order to prevent treatment failures - but they seldom re-evaluate this initial therapy even when it is not necessary or too broad, and they often treat for too long.

It is time to react vigorously in order to protect and save antibiotics, and try to break this downward spiral of resistance. A strong cooperation between healthcare professionals - in both human and animal medicine and consumers is therefore needed, providing simple but

\footnotetext{
*Correspondence: jeancarlet@gmail.com

IIntensive care specialist, Consultant, 9 rue de la Terrasse, Creteil 94000, France Full list of author information is available at the end of the article
}

powerful and convincing information to the politicians and the public. Antibiotics must have a special status, with specific rules, regulations, and controls. Diagnostic tests must be developed to help clinicians know when not to treat, and to focus antibacterial therapy only on bacterial infections. Research must be facilitated, particularly to accelerate the development of new compounds. Infection control must be upgraded, in particular to emphasise the use of hand-rub alcoholic solutions, in the hospitals and in the community. The vaccination programme must be an absolute priority. Finally, a strong educational programme is of paramount importance, for both healthcare professionals and consumers.

For those purposes, on 7 April we created a World Alliance against multi-drug-resistant bacteria - the World Alliance against Antibiotic Resistance (WAAR). This Alliance will have the statutes of a French association loi 1901. The WAAR gathers 350 professionals from many aspects of human and animal medicine who support this alliance, as well as 54 medical specialties or professional bodies all around the world. Eighty wellknown international experts, including many intensivists, from 41 different countries constitute our international scientific advisory committee. Consumers from France via Le Lien and Le CISS are fully involved in the WAAR, inviting consumers from other countries to join (in particular, the Patients for Patient Safety at the World Health Organization, and the Association des victimes d'infection nosocomiale in Quebec). The alliance will contact organisations such as the World Organization for animal Health (OIE), the World Health Organization, and the European Centre for Diseases Control. Ministers of Health and other key politicians will be contacted by the members of the WAAR, in each country. Some deputies in France are already members of the Alliance. Of course, contacts with other groups (React, Action Antibiotics, Alliance for a Prudent USe of Antibiotics (APUA), and so forth) are essential, and have already been taken. 
The Barcelona Declaration was launched during the 17th Congress on Infections in Critically Ill Patients on 4 February 2012 [3]. Intensive care specialists and consumers from many countries, including France, the USA, Spain, Italy and Portugal, have declared war against multi-resistant bacteria in the ICU, and call their colleges worldwide to participate in the project. ICUs are epicentres for resistance development, because $80 \%$ of the patients are treated with antibiotics at any time and because the risk of cross-transmission is very high. A few years ago very successful results were obtained with methicillin-resistant Staphylococcus aureus in the ICU, where the incidence of this bug was decreased by 10-fold [4]. Similar results are possible to reach with Escherichia coli and Klebsiella pneumoniae carrying extendedspectrum $\beta$-lactamases and Pseudomonas and Acinetobacter spp. Patients at risk of carrying carbapenemases, such as NDM1, must be detected and isolated prospectively. Standard precautions must be upgraded and systematically applied for every patient. We engage ourselves to use antibiotics wisely, only when necessary, and to systematically re-evaluate therapy at day 2 or 3 of therapy. This last point is absolutely key for the success of the programme. Regular feedback on the effect of this programme (antibiotic consumption and resistance) will be provided on a regular basis during this international meeting devoted to infections in critically ill patients.

Abbreviations

WAAR, World Alliance against Antibiotic Resistance.

\section{Competing interests}

MSN acts as a consultant for Pfizer, Merck, Paratek and Glaxo-Smith Kline. All the remaining authors declare that they have no competing interests.

\section{Author details}

"Intensive care specialist, Consultant, 9 rue de la Terrasse, Creteil 94000 France. ${ }^{2}$ Director of Critical Care Center, Sabadell Hospital, Corporació Sanitaria Universitaria Parc Tauli, Professor of Applied Physiology, Autonomous University of Barcelona, Spain. ${ }^{3}$ Chairman, Department of Medicine, WinthropUniversity Hospital, Professor of Medicine, Vice-Chairman, Department of Medicine, SUNY at Stony Brook, 222 Station Plaza N., Suite 509, Mineola, NY 11501, USA. ${ }^{4}$ Pneumology Department, Clinic Institute of Thorax (ICT), Hospital Clinic of Barcelona, Insitut d'Investigacions Biomèdiques August Pi i Sunyer (IDIBAPS), University of Barcelona (UB), Spain.

Published: 3 August 2012

\section{References}

1. Carlet J, Collignon P, Goldmann D, Goossens H, Gyssens IC, Harbarth S, Jarlier V, Levy SB, N'Doye B, Pittet D, Richtmann R, Seto WH, van Der Meer JWM, Voss A: Society's failure to protect a precious resource: antibiotics. Lancet 2011, 378:369-371.

2. Carlet J, Mainardi JL: Antibacterial agents: back to the future. Can we live with only colistine, co-trimoxazole, and fosfomycin. Clin Microbial Infect 2012, 18:1-3

3. Torres A, Niederman M, Artigas A, Carlet J: Pulmonary infections and antibiotic resistance: recent information. Expert Rev Anti-infect Ther 2012, in press.

4. Jarlier V, Trystram D, Brun-Buisson C, Fournier S, Carbonne A, Marty L, Andremont A, Arlet G, Buu-Hoi A, Carlet J, Decré D, Gottot S, Gutmann L, Joly-Guillou ML, Legrand P, Nicolas-Chanoine MH, Soussy CJ, Wolf M, Lucet JC, Aggoune M, Brücker G, Régnier B; Collégiale de Bactériologie-VirologieHygiène des Hôpitaux Universitaires de I'lle de France: Curbing methicillinresistant Staphylococcus aureus in 38 French hospitals through a 15-year institutional control program. Arch Intern Med 2010, 170:552-559.

doi:10.1186/cc11427

Cite this article as: Carlet JM, et al:: The Barcelona Declaration from the World Alliance against Antibiotic Resistance (WAAR): engagement of intensivists. Critical Care 2012, 16:145. 